ORIGINAL

\title{
Presence of gastrointestinal parasites in swine and human of four swine production farms in Cundinamarca- Colombia
}

\section{Presencia de parásitos gastrointestinales en cerdos y humanos de cuatro granjas porcícolas de Cundinamarca- Colombia}

\author{
María F Mendoza-Gómez, ${ }^{1}$ Bact, Adriana Pulido-Villamarín, ${ }^{1 *}$ M.Sc, \\ Angélica Barbosa-Buitrago, ${ }^{2}$ MV, Moisés Aranda-Silva, ${ }^{3}$ M.Sc.
}

\begin{abstract}
${ }^{1}$ Pontificia Universidad Javeriana, Facultad de Ciencias, Departamento de Microbiología, Unidad de Investigaciones Agropecuarias (UNIDIA). Bogotá, Colombia. Carrera $7^{\circ} \mathrm{N}^{\circ}$ 43-82 Edificio 52 Oficina 608, Telf 57-1-3208320 ext 4020. 'Universidad El Bosque Maestría en Ciencias Biomédicas, Práctica privada. Bogotá, Colombia. ${ }^{3}$ Pontificia Universidad Javeriana, Facultad de Ciencias, Departamento de Matemáticas. Bogotá, Colombia. *Correspondencia: adriana.pulido@javeriana.edu.co
\end{abstract}

Received: February 2015; Acepted: May 2015.

\begin{abstract}
Objectives. Determine the presence and the type of endoparasites with zoonotic potential in swine and human of two technified and two semi-technified farms in the department of Cundinamarca, Colombia. Materials and methods. Three serial samplings of feces were taken in a pen row within intervals of 15 days, in two technified and two semi-technified farms in different age groups distributed as follows: pregnant-sows, nursing-females, boars, weaners, suckling-piglets, and growing-pig. By means of informed consent thirty-three people agreed to enter the study. Thirty-three samples from men and women of different ages were received. The pool and individual samples of fecal were evaluated by direct analysis, qualitative flotation and sedimentation techniques and modified ZiehlNeelsen stain. Results. For the porcine population, on the average, the results obtained from both technified farms showed that Balantidium coli (42\%), Endolimax nana (21.9\%) and Iodamoeba bütschlii $(7.8 \%)$ were the most common parasites. In semi-technified farms they were: Entamoeba coli (40\%), Endolimax nana (35\%), Iodamoeba bütschlii (25\%) and Balantidium coli (5\%). By means of the test $\mathrm{chi}^{2}$ it is possible to conclude that there is a significant difference between the parasites species and the type of farm. The results obtained in human showed the presence of parasites as: $E$. coli $(42.2 \%)$, Entamoeba hystolitica/dispar (12.1\%), E. nana (9.1\%), B. coli $(9.1 \%)$, I. bütschlii $(3.0 \%)$ and Blastocystis hominis (3.0\%). Conclusions. The presence of parasites such as Balantidium coli, Endolimax nana, Iodamoeba bütschlii and Entamoeba coli in swine and human suggests a possible rotation of parasitic species between hosts.
\end{abstract}

Key words: Parasites, swine, zoonoses (Source: DeSC).

\section{RESUMEN}

Objetivos. Determinar la presencia y el tipo de endoparásitos con potencial zoonótico en porcinos y humanos de dos granjas tecnificadas y dos semi-tecnificadas del departamento de CundinamarcaColombia. Materiales y métodos. Se realizaron tres muestreos seriados de materia fecal con intervalos de 15 días, en dos granjas tecnificadas ( 92 muestras) y dos semi-tecnificadas (60 muestras) en diferentes grupos etarios distribuidos así: Hembras de cría, hembras de reemplazo, reproductores, lechones, pre-cebo y ceba. Se recibieron 33 muestras de hombres y mujeres de diferentes edades, 
que mediante consentimiento informado asintieron participar en el estudio. Las muestras de materia fecal colectivas e individuales (de humanos y de cerdos) fueron evaluadas mediante: Análisis directo, técnica de flotación cualitativa, técnica de sedimentación cualitativa y tinción de Ziehl-Neelsen modificado. Resultados. En promedio para la población porcina, los resultados obtenidos de las dos granjas tecnificadas mostraron que los parásitos en común son Balantidium coli (42\%), Endolimax nana $(21.9 \%)$ y Iodamoeba bütschlii $(7.8 \%)$. En las dos granjas semi-tecnificadas: Entamoeba coli $(40 \%)$, Endolimax nana (35\%), Iodamoeba bütschlii (25\%) y Balantidium coli (5\%). Por medio de la prueba $\mathrm{Chi}^{2}$ se puede concluir que hay una diferencia significativa entre la especie de parásitos y el tipo de granja. Los resultados obtenidos en humanos mostraron la presencia de parásitos como: E. coli $(42.2 \%)$, Entamoeba hystolitica/dispar (12.1\%), E. nana (9.1\%), B. coli $(9.1 \%)$, I. bütschlii $(3.0 \%)$ y Blastocystis hominis $(3.0 \%)$. Conclusiones. La presencia de parásitos como Balantidium coli, Endolimax nana, Iodamoeba bütschlii y Entamoeba coli en cerdos y humanos sugiere una posible rotación de especies parásitas entre los hospedadores.

Palabras clave: Parásitos, porcinos, zoonosis (Fuente: DeSC).

\section{INTRODUCTION}

In Colombia, during the year 2013 the porcine production was 670.612 animals, to which Cundinamarca contributed $4.98 \%$ (1); 1.458 .179 pigs were slaughtered for human consumption between January and June of 2013, Cundinamarca contributed $20.1 \%$ (650.035 pigs)(1).

This type of animal production is affected by the presence of parasites that limit the productive potential of the animals, thus affecting the average daily weight gain, causing heterogeneous lots as well as facilitating weight decrease during weaning, which seems reflected in the alteration of the food conversion indexes and further represents an increase in the time required before slaughter (2). It is important to note the rate of prevalence and the economic importance of the parasites changes depending on the management system, the housing characteristics, the hygienic-sanitary measures, the geographic location and the age of the pig. Thus, all these variables influence the basic requirements of every stage of the parasitic cycle, in both the mechanisms of transmission and the immune response of the host (3).

The parasites that have a major impact on health and porcine production are protozoan parasites such as Eimeria spp., Isospora spp. and Balantidium spp.; worm infections reported were primarily nematodes (such as Trichinella spp., Strongylus spp., Ascaris spp., Trichuris spp., Oesophagostomum spp. and Metastrongylus spp.) secondarily trematodes (such as Fasciola spp. and Dicrocoelium spp.) and finally cestodes (such as Echinococcus spp. and Taenia solium) $(4,5)$. Many of these pathogens affect porcine production and can be transmitted to humans, and are recognized as zoonotic agents (6) among these we can find Balantidium coli, Toxoplasma gondii, Cryptosporidium spp. and Taenia solium (7).

\section{INTRODUCCIÓN}

En Colombia, durante el año 2013 la producción porcina fue de 670.612 animales, de los cuales Cundinamarca contribuyó con el $4.98 \%$ (1); se sacrificaron 1'458.179 cerdos para el consumo humano entre enero y junio de 2013 y Cundinamarca contribuyó con el 20.1\% (650.035 cerdos) (1).

Este tipo de producción animal se ve afectada por la presencia de parásitos que limitan el potencial productivo de los animales, lo que disminuye la ganancia media diaria de peso, provoca lotes heterogéneos y facilita la disminución de peso durante el destete, lo que se refleja en la alteración de los índices de conversión alimentaria; además, representa un aumento en el tiempo necesario antes del sacrificio (2). Es importante resaltar que la tasa de prevalencia y la implicación económica de las parasitosis, varía notablemente y dependen del sistema de manejo, de las características del alojamiento, de las medidas higiénico-sanitarias, la localización geográfica de la explotación y la edad del cerdo; influyendo todas estas variables en los requerimientos básicos de todos los estadios del ciclo parasitario, en los mecanismos de transmisión y en la respuesta inmune del hospedero (3).

Los parásitos que tienen mayor impacto sobre la salud y la producción porcícola son protozoos como Eimeria spp., Isospora spp. y Balantidium spp.; en cuanto a los helmintos se reportan principalmente nemátodos (Trichinella spp., Strongylus spp., Ascaris spp., Trichuris spp., Oesophagostomum spp., y Metastrongylus spp.), en segundo lugar tremátodos (Fasciola spp., y Dicrocoelium spp.) y finalmente céstodos (Echinococcus spp., y Taenia solium) $(4,5)$. Muchos de los patógenos que afectan la producción porcina pueden ser transmitidos al ser humano, por lo que son reconocidos como agentes zoonóticos (6) entre los que se 
In Colombia, few epidemiological studies have been made in the matter, which is why not much information is known about the prevalence of porcine parasites. Therefore, it is of vital importance to conduct studies on the topic in order to know which are really parasites of zoonotic importance in this country. Thus the goal of this study was to determine the presence of gastrointestinal parasites (GIP) in swine and human who could be involved with zoonoses at four swine farms in the department of Cundinamarca - Colombia.

\section{MATERIALS AND METHODS}

Farm's Location. Two technified swine farms ( $T$ ) ( $\geq 200$ females) and two semi-technified farms (ST) ( $\leq 200$ females) with a complete cycle of production with an all in/all out system (AI-AO), were chosen in the following locations

Farm 1 (T1): Located at a height of 1.728 (m.a.s.l.), with an average temperature of $20^{\circ} \mathrm{C}$ (8) and a population of 3654 pigs.

Farm 2 (T2): Located at a height of 2.586 (m.a.s.l.), with an average temperature of $14^{\circ} \mathrm{C}$ (8) and a population of 2156 pigs.

Farm 3 (ST1): Located at a height of 1.867 (m.a.s.l.), with an average temperature of $20^{\circ} \mathrm{C}(9)$ and a population of 244 pigs.

Farm 4 (ST2): Located at a height of 1.384 (m.a.s.l.), with an average temperature of $20^{\circ} \mathrm{C}(9)$ and a population of 125 pigs.

Sample size. Bearing in mind that the total population was less than a 100.000 (finite population), the following formula was used to calculate the sampling size (Table 1 ).

Where: $n=\frac{Z^{2} p q}{E^{2} Z^{2} \frac{p q}{N}}$

Table1. Amount of samples obtained per age group in the swine farms in Cundinamarca.

\begin{tabular}{lcccccc}
\hline & \multicolumn{3}{c}{ Technified Farms } & \multicolumn{3}{c}{ Semi-technified farms } \\
\hline Age Group & T1 & T2 & Total & ST1 & ST2 & Total \\
Pregnant sows & 7 & 12 & $\mathbf{1 9}$ & 6 & 11 & $\mathbf{1 7}$ \\
Nursing females & 1 & 1 & $\mathbf{2}$ & 4 & 3 & $\mathbf{7}$ \\
Boars & 1 & 1 & $\mathbf{2}$ & 1 & 2 & $\mathbf{3}$ \\
Weaners & 6 & 14 & $\mathbf{2 0}$ & 1 & 4 & $\mathbf{5}$ \\
Suckling piglets & 16 & 8 & $\mathbf{2 4}$ & 3 & 13 & $\mathbf{1 6}$ \\
Growing-pig & 10 & 15 & $\mathbf{2 5}$ & 5 & 7 & $\mathbf{1 2}$ \\
\hline Total & $\mathbf{4 1}$ & $\mathbf{5 1}$ & $\mathbf{9 2}$ & $\mathbf{2 0}$ & $\mathbf{4 0}$ & $\mathbf{6 0}$ \\
\hline
\end{tabular}

encuentra Balantidium coli, Toxoplasma gondii, Cryptosporidium spp. y Taenia solium (7).

En Colombia, se han realizado pocos estudios epidemiológicos sobre este tema y debido a esto no se conoce con certeza cuál es la prevalencia de los parásitos porcinos. Por lo tanto, es importante realizar estudios al respecto con el fin de conocer cuáles son los parásitos de importancia zoonótica en este país. De esta manera la meta del presente estudio fue determinar la presencia de parásitos gastrointestinales (PGI) en porcinos y humanos que podrían estar involucrados zoonóticamente en las cuatro granjas porcinas en el departamento de Cundinamarca - Colombia.

\section{MATERIALES Y MÉTODOS}

Localización de las granjas. Se analizaron dos granjas porcícolas tecnificadas (T) ( $\geq 200$ hembras) y dos granjas semi-tecnificadas (ST) ( $\leq$ 200 hembras) con ciclo completo de producción con sistema todo dentro-todo fuera (TD-TF), ubicadas así:

Granja 1 (T1): Localizada a una altura de 1.728 (m.s.n.m.) con una temperatura promedio de $20^{\circ} \mathrm{C}(8)$ y una población de 3.654 cerdos.

Granja 2 (T2): Localizada a una altura de 2.586 (m.s.n.m.) con una temperatura promedio de $14^{\circ} \mathrm{C}(8)$ y una población de 2.156 cerdos.

Granja 3 (ST1): Localizada a una altura de 1.867 (m.s.n.m.) con una temperatura promedio de $20^{\circ} \mathrm{C}$ (9) y una población de 244 cerdos.

Granja 4 (ST2): Localizada a una altura de 1.384 (m.s.n.m.) con una temperatura promedio de $20^{\circ} \mathrm{C}$ (9) y una población de 125 cerdos.

Tamaño de la muestra. Teniendo en cuenta que la población total era menor de 100.000 (población finita), se utilizó la siguiente fórmula para calcular el tamaño de la muestra (Tabla 1).

Donde:

$$
n=\frac{Z^{2} p q}{E^{2} Z^{2} \frac{p q}{N}}
$$

Z: Nivel de certeza

P: Proporción estimada de acuerdo con la hipótesis a analizar ( $55 \%$ prevalencia promedio reportada) (10-12)

q: $1-p$

$\mathrm{N}$ : Número total de individuos

E: Error definido para este cálculo (10\%) 
Z: Level of certainty

$\mathrm{p}$ : Estimator of the proportion according to the hypothesis to be analyzed (55\% average prevalence reported) (10-12)

$q: 1-p$

$\mathrm{N}$ : Total number of individuals or units in the study

E: Error component for this calculation (10\%).

Sample collection. Collective and individual samples (Figure 1) were obtained according to the phases of the productive cycle as follows:

Group 1 Individual Samples: Pregnant sows, Nursing Females, boars.

Group 2 Collective Samples: Weaners, Suckling Piglets, Growing-pig.

Three samples were taken within an interval of 15 days each.

The farm workers and some of their relatives gave us a stool sample; 18 samples were received (12 men, 4 women and 2 children) from the technified farms, and 15 samples ( 7 men, 5 women and 3 children) from the semitechnified farms.

Ethical aspects. The animal management of the and the samples were taken according with Colombian laws (Decree 2257 of 1986, Article 49 and Resolution 8430 of 1993

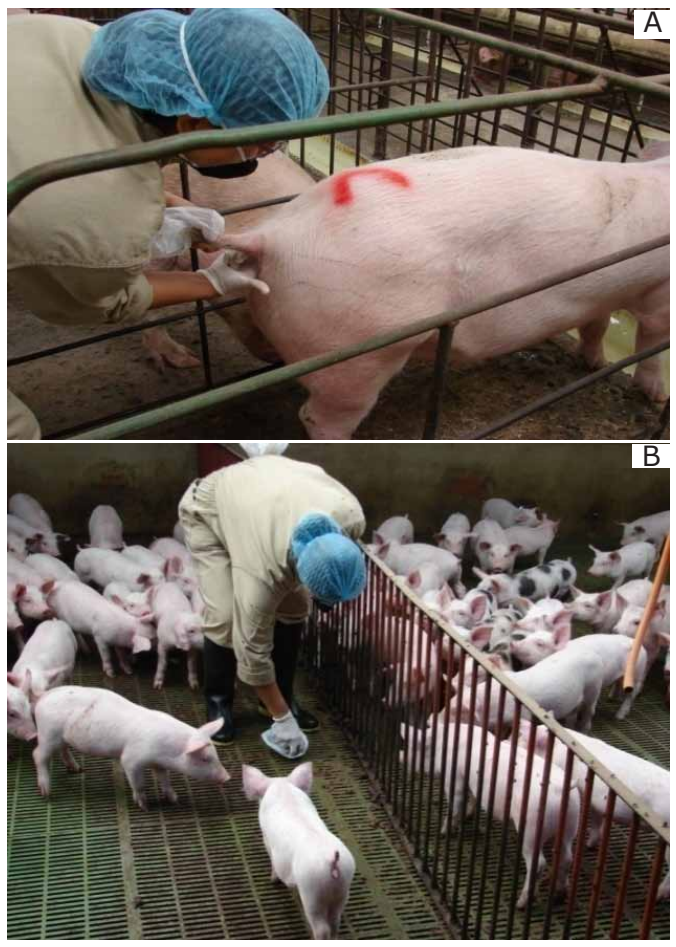

Recolección de las muestras. Se obtuvieron muestras colectivas e individuales (Figura 1) de acuerdo con las fases del ciclo productivo de la siguiente manera:

Grupo 1 Muestras individuales: Hembras gestantes, hembras lactantes y reproductoras.

Grupo 2 Muestras colectivas: Lechones destetados, lechones lactantes, cerdos de levante.

Se realizaron tres muestreos con un intervalo de 15 días cada uno.

Los trabajadores de las granjas y algunos de sus familiares asintieron al respectivo consentimiento informado, proporcionando una muestra de materia fecal cada uno; se recibieron 18 muestras (12 de hombres, 4 de mujeres y 2 de niños) de las granjas tecnificadas, y 15 muestras ( 7 de hombres, 5 de mujeres y 3 de niños) de las granjas semitecnificadas.

Aspectos éticos. El manejo de los animales y la obtención de las muestras fueron realizadas de acuerdo con las leyes colombianas (Decreto 2257 de 1986, artículo 49 y Resolución 8430 de 1993, Título IV: Investigación sobre bioseguridad, Capítulo I Respecto a la investigación con microorganismos patógenos o con material biológico que pueda contenerlos, de conformidad con las actividades relacionadas con la investigación, la prevención y el control de la zoonosis).

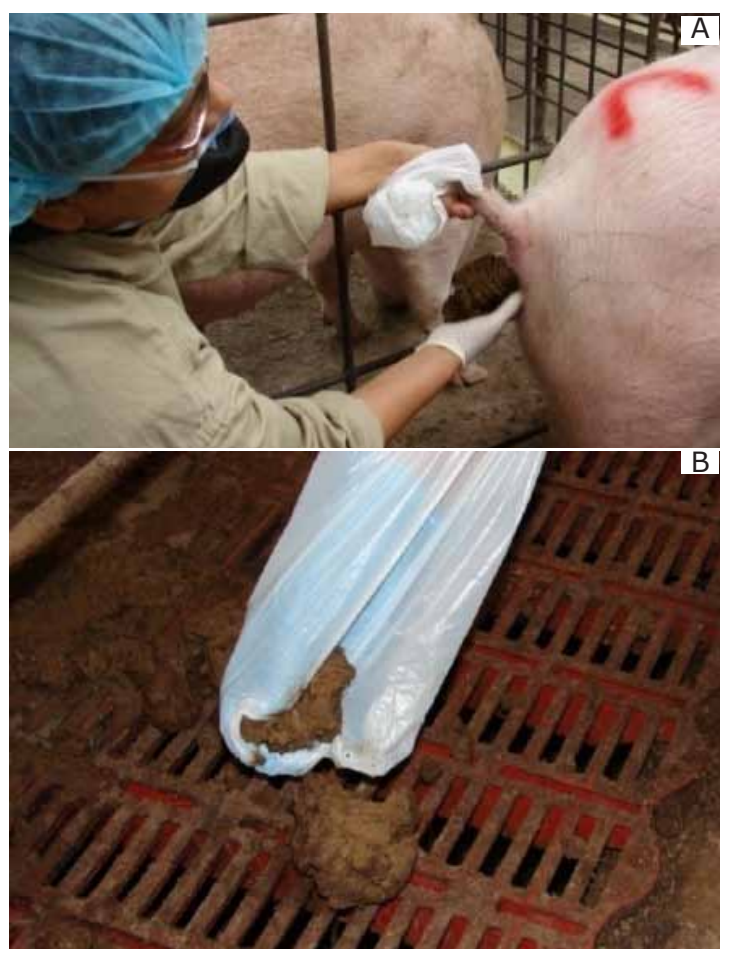

Figure 1. A. Individual sample gathering - Manual stimulation of the rectum B. Collective Sample gathering. 
TITLE IV: Regarding Research bio-safety, CHAPTER I Regarding research with pathogenic microorganisms or biological material that may contain them concerning research activities related to investigation, prevention and control of zoonosis).

Everyone that entered the study signed an informed consent form as established in Decree 3380 of 1981 Article 10 of Law 23 of 1981 wherein medical ethic laws are established.

\section{Sample processing}

Macroscopic and microscopic approach. Macroscopic aspects such as color, consistency, presence of mucus, blood and/or parasites/ fragments were evaluated.

A direct examination was conducted in saline and lugol solution, under $10 x$ and $40 x$ magnification; the report of the results obtained was made using a semi quantitative scale with crosses, as follows:

One cross (+) if 1 to 3 parasites per field are present.

Two crosses $(++)$ if 4 to 7 parasites per field are present.

Three crosses $(+++)$ if 8 to 10 parasites per field are present.

Four crosses $(++++)$ if more than 10 parasites per field are present. $(13,14)$

Semi quantitative concentration method based on flotation. $2 \mathrm{~g}$ of fecal matter were deposited in a wide flask with a saturated solution of sodium chloride and glucose, the procedure was made according to what is established in the guide RVC/FAO (15). A direct examination was conducted in the microscope, under 10x and 40x magnification; the report of the results obtained was made using a semi quantitative scale with crosses as previous described $(13,14)$.

Semi quantitative concentration method based on sedimentation. $2 \mathrm{~g}$ of fecal matter were homogenized in water; the procedure was made according to what is established in the guide RVC/ FAO (15), finally with the aid of a pipette Pasteur the sediment was taken and a drop of it was placed in a microscope slide, using magnification $10 x$ and $40 \mathrm{x}$; the report of the results obtained was made using a semi quantitative scale $(13,14)$.

Ziehl-Neelsen modified method. From the sediment taken, a smear study was made on a slide as follows: first by adding carbol fuchsin for $5 \mathrm{~min}$ and then washed with abundant water, later acid alcohol was added up to the complete discoloration for not more than 3 minutes, then
Todas las personas que participaron en el estudio firmaron un consentimiento informado según lo establecido en el Decreto 3380 de 1981, artículo 10 y la Ley 23 de 1981, en donde se establecen las leyes de ética médica.

\section{Procesamiento de las muestras}

\section{Evaluación macroscópica y microscópica}

Se evaluaron aspectos macroscópicos tales como color, consistencia, presencia de mocusidad, sangre o fragmentos de parásitos.

Se realizó un examen directo en solución salina y lugol, con aumentos de 10x y 40x; el reporte de los resultados se efectuó utilizando una escala semicuantitativa con cruces, tal como se muestra a continuación:

Una cruz (+) si están presentes de 1 a 3 parásitos por campo.

Dos cruces $(++)$ si están presentes de 4 a 7 parásitos por campo.

Tres cruces $(+++)$ si están presentes de 8 a 10 parásitos por campo.

Cuatro cruces $(++++)$ si están presentes más de 10 parásitos por campo. $(13,14)$

Método semi-cuantitativo de concentración por flotación. Se depositaron $2 \mathrm{~g}$ de materia fecal en un frasco de boca ancha con una solución saturada de cloruro de sodio y glucosa; el procedimiento se realizó de acuerdo con lo establecido en la guía RVC / FAO (15). Se hizo observación microscópica bajo aumentos de 10x y 40x; el informe de los resultados se realizó utilizando una escala semicuantitativa por cruces tal como se describió anteriormente $(13,14)$.

Método de concentración semicuantitativa por sedimentación. Se homogenizaron en agua $2 \mathrm{~g}$ de materia fecal; el procedimiento se realizó de acuerdo con lo establecido en la guía RVC/FAO (15); finalmente con la ayuda de una pipeta Pasteur se tomó el sedimento y se colocó una gota en una lámina portaobjetos con solución salina y lugol para observar al microscopio bajo el objetivo de 10X y $40 \mathrm{X}$, el informe de los resultados obtenidos se hizo utilizando una escala semicuantitativa $(13,14)$.

Método de Ziehl-Neelsen modificado. A partir del sedimento, se realizó un extendido sobre una lámina portaobjeto, después se adicionó fucsina fenicada por 5 min y se lavó con abundante agua, posteriormente se adicionó alcohol-ácido hasta decoloración completa por un tiempo no superior a 3 minutos, luego se aplicó azul de metileno por 2 min, finalmente se lavó con abundante agua. Las 
methylene blue was applied by 2 min, finally the sample was washed with abundant water. The samples were analyzed under light microscopy using magnifications 40x and 100x(16).

Statistical analysis. To determine the relationship between the parasites species Vs. the production system and the age groups, the statistical test $\mathrm{Chi}^{2}$ was applied, additionally the portion of parasites was determined by the test of proportion hypothesis. The data analysis obtained in the human samples was done by the presence or absence of parasites.

\section{RESULTS}

Porcine population. In the farm $\mathrm{T} 1$ a high presence of Balantidium coli $36.6 \%$ was found, followed by Ascaris suum 29.2\%, Endolimax nana $15.2 \%$, Giardia spp. $12.1 \%$ and by a low prevalence of Iodamoeba bütschlii $7.5 \%$ and Trichuris suis $4.8 \%$. On the other hand in farm T2 a high presence of $B$. coli $48.5 \%$ and $E$. nana $26.4 \%$ was found, followed by a low presence of $I$. bütschlii $8.2 \%$ and Strongyloides spp. 5.8\%. (Table 2)

Fort the semi-technified farms, in ST1 a high presence of $I$. bütschlii $57.1 \%$, B. coli $33.3 \%$, E. nana $14.2 \%$ was found, followed by a low presence of Cryptosporidium spp. 5\% and $E$. coli $4.7 \%$. Finally in farm ST2 the parasites with a high presence were: E. coli $40 \%$, E. nana 35\%, I. bütschlii $25 \%$, Isospora spp. $25 \%$, Eimeria spp. $20 \%$ and a low presence of B. coli $5 \%$. (Table 3) preparaciones fueron analizadas bajo microscopía de luz en 40x y 100x (16).

Análisis estadístico. Para determinar la relación existente entre especie parásita vs sistema de producción y grupos etarios se realizó la prueba estadística $\mathrm{Chi}^{2}$, adicionalmente se determinó la proporción de parásitos en las granjas tecnificadas y semi- tecnificadas, esto se realizó por medio de la prueba de hipótesis con proporciones. El análisis de los datos obtenidos en las muestras humanas, se realizó por presencia o ausencia de parásitos.

\section{RESULTADOS}

Población porcina. En la granja T1 se encontró alta presencia de Balantidium coli $36.6 \%$, seguida por Ascaris suum 29.2\%, Endolimax nana $15.2 \%$, Giardia spp. $12.1 \%$ y baja prevalencia de Iodamoeba bütschlii $7.5 \%$ y Trichuris suis $4.8 \%$. Mientras, en la granja T2 se encontró alta presencia de B. coli $48.5 \%$ y E. nana $26.4 \%$, seguido por una baja presencia de $I$. bütschlii $8.2 \%$ y Strongyloides spp. $5.8 \%$. (Tabla 2 )

Para las granjas semi-tecnificadas, en ST1 se encontró alta presencia de $I$. bütschlii $57.1 \%, B$. coli $33.3 \%$, E. nana $14.2 \%$, seguido por una baja presencia de Cryptosporidium spp. $5 \%$ y E. coli 4.7\%. Finalmente en la granja ST2 los parásitos con alta presencia fueron $E$. coli $40 \%$, E. nana $35 \%$, I. bütschlii $25 \%$, Isospora spp. $25 \%$, Eimeria spp. $20 \%$ y con baja presencia B. coli $5 \%$. (Tabla 3 )

Table 2. Presence of gastrointestinal parasites per age group in technified swine farms by percentage.

\begin{tabular}{|c|c|c|c|c|c|c|c|}
\hline & & B. coli & E. nana & I. bütschlii & A. suum & T. suis & Giardia spp. \\
\hline \multirow[b]{2}{*}{ Farm T1 } & \multirow{2}{*}{ Pregnant sows } & 37.5 & 37.5 & 37.5 & 50 & 0 & 0 \\
\hline & & $\begin{array}{l}3 \\
100\end{array}$ & $\begin{array}{l}3 \\
0\end{array}$ & $\stackrel{2}{100}$ & $\begin{array}{c}4 \\
100\end{array}$ & $\begin{array}{l}0 \\
0\end{array}$ & $\begin{array}{c}0 \\
100\end{array}$ \\
\hline \multirow{5}{*}{$\begin{array}{c}\% \\
\mathrm{n}\end{array}$} & Nursing Females & $\begin{array}{c}1 \\
66.6\end{array}$ & $\begin{array}{l}0 \\
0\end{array}$ & $\begin{array}{l}1 \\
0\end{array}$ & $\begin{array}{c}1 \\
33.3\end{array}$ & $\begin{array}{l}0 \\
0\end{array}$ & $\begin{array}{c}1 \\
16.6\end{array}$ \\
\hline & Weaners & $\begin{array}{c}4 \\
56.25\end{array}$ & $\begin{array}{c}0 \\
18.7\end{array}$ & $\begin{array}{l}0 \\
0\end{array}$ & $\begin{array}{c}2 \\
31.2\end{array}$ & $\begin{array}{c}0 \\
12.5\end{array}$ & $\stackrel{2}{12.5}$ \\
\hline & Suckling Piglets & $\begin{array}{l}9 \\
0\end{array}$ & $\begin{array}{c}3 \\
20\end{array}$ & $\begin{array}{l}0 \\
0\end{array}$ & $\begin{array}{l}5 \\
0\end{array}$ & $\begin{array}{l}2 \\
0\end{array}$ & $\begin{array}{c}1 \\
10\end{array}$ \\
\hline & Growing-pig & $\begin{array}{l}0 \\
0\end{array}$ & $\begin{array}{l}2 \\
0\end{array}$ & $\begin{array}{l}0 \\
0\end{array}$ & $\begin{array}{l}0 \\
0\end{array}$ & $\begin{array}{l}0 \\
0\end{array}$ & $\begin{array}{l}1 \\
0\end{array}$ \\
\hline & Boars & 0 & 0 & 0 & 0 & 0 & 0 \\
\hline \multirow[b]{2}{*}{ Farm T2 } & \multirow{2}{*}{ Pregnant sows } & 30.8 & 0 & 15.3 & 0 & 0 & 0 \\
\hline & & $\begin{array}{c}4 \\
100\end{array}$ & $\begin{array}{l}0 \\
0\end{array}$ & $\stackrel{2}{100}$ & $\begin{array}{l}0 \\
0\end{array}$ & $\begin{array}{l}0 \\
0\end{array}$ & $\begin{array}{l}0 \\
0\end{array}$ \\
\hline \multirow{5}{*}{$\begin{array}{l}\% \\
\mathrm{n}\end{array}$} & Nursing Females & $\begin{array}{c}1 \\
14.2\end{array}$ & $\begin{array}{c}0 \\
7.1\end{array}$ & $\begin{array}{l}1 \\
0\end{array}$ & $\begin{array}{l}0 \\
0\end{array}$ & $\begin{array}{l}0 \\
0\end{array}$ & $\begin{array}{l}0 \\
0\end{array}$ \\
\hline & Weaners & $\begin{array}{c}2 \\
50\end{array}$ & $\begin{array}{c}1 \\
25\end{array}$ & $\begin{array}{c}0 \\
12.5\end{array}$ & $\begin{array}{l}0 \\
0\end{array}$ & $\begin{array}{l}0 \\
0\end{array}$ & $\begin{array}{l}0 \\
0\end{array}$ \\
\hline & Suckling Piglets & $\begin{array}{c}2 \\
40\end{array}$ & $\begin{array}{l}2 \\
0\end{array}$ & $\begin{array}{c}1 \\
13.3\end{array}$ & $\begin{array}{l}0 \\
0\end{array}$ & $\begin{array}{l}0 \\
0\end{array}$ & $\begin{array}{l}0 \\
0\end{array}$ \\
\hline & Growing-pig & $\begin{array}{c}6 \\
100\end{array}$ & $\begin{array}{c}0 \\
100\end{array}$ & $\begin{array}{l}2 \\
0\end{array}$ & $\begin{array}{l}0 \\
0\end{array}$ & $\begin{array}{l}0 \\
0\end{array}$ & $\begin{array}{l}0 \\
0\end{array}$ \\
\hline & Boars & 1 & 1 & 0 & 0 & 0 & 0 \\
\hline
\end{tabular}


Table 3. Presence of gastrointestinal parasites per age group in semi-technified swine farms by percentage.

\begin{tabular}{|c|c|c|c|c|c|c|c|c|}
\hline & & B. coli & E. nana & I. bütschlii & Isospora spp. & Eimeria spp. & Entamoeba coli & Cryptosporidium spp. \\
\hline \multirow{7}{*}{$\begin{array}{c}\text { Farm ST1 } \\
\% \\
n\end{array}$} & \multirow{2}{*}{ Pregnant sows } & 33.3 & 33.3 & 66.6 & 0 & 0 & 0 & 0 \\
\hline & & $\begin{array}{c}2 \\
50\end{array}$ & $\begin{array}{l}2 \\
0\end{array}$ & $\begin{array}{c}4 \\
50\end{array}$ & $\begin{array}{l}0 \\
0\end{array}$ & $\begin{array}{l}0 \\
0\end{array}$ & $\begin{array}{l}0 \\
0\end{array}$ & $\begin{array}{c}0 \\
25\end{array}$ \\
\hline & Nursing Females & $\begin{array}{l}2 \\
0\end{array}$ & $\begin{array}{l}0 \\
0\end{array}$ & $\stackrel{2}{100}$ & $\begin{array}{l}0 \\
0\end{array}$ & $\begin{array}{l}0 \\
0\end{array}$ & $\begin{array}{l}0 \\
0\end{array}$ & $\begin{array}{l}1 \\
0\end{array}$ \\
\hline & Weaners & $\begin{array}{c}0 \\
33.3\end{array}$ & $\begin{array}{c}0 \\
33.3\end{array}$ & $\begin{array}{c}1 \\
33.3\end{array}$ & $\begin{array}{l}0 \\
0\end{array}$ & $\begin{array}{l}0 \\
0\end{array}$ & $\begin{array}{l}0 \\
0\end{array}$ & $\begin{array}{c}0 \\
66.6\end{array}$ \\
\hline & Suckling Piglets & $\begin{array}{l}1 \\
0\end{array}$ & $\begin{array}{l}1 \\
0\end{array}$ & $\begin{array}{c}1 \\
40\end{array}$ & $\begin{array}{l}0 \\
0\end{array}$ & $\begin{array}{l}0 \\
0\end{array}$ & $\begin{array}{l}0 \\
0\end{array}$ & $\begin{array}{l}2 \\
0\end{array}$ \\
\hline & Growing-pig & $\begin{array}{l}0 \\
0\end{array}$ & $\begin{array}{l}0 \\
0\end{array}$ & $\begin{array}{l}2 \\
0\end{array}$ & $\begin{array}{l}0 \\
0\end{array}$ & $\begin{array}{l}0 \\
0\end{array}$ & $\begin{array}{l}0 \\
0\end{array}$ & $\begin{array}{l}0 \\
0\end{array}$ \\
\hline & Boars & 0 & 0 & 0 & 0 & 0 & 0 & 0 \\
\hline \multirow{6}{*}{$\begin{array}{c}\text { Farm ST2 } \\
\% \\
n\end{array}$} & \multirow{2}{*}{ Pregnant sows } & 9 & 36.3 & 27.2 & 27.2 & 9 & 54.5 & 0 \\
\hline & & $\begin{array}{l}1 \\
0\end{array}$ & 33.3 & 33.3 & $\begin{array}{l}3 \\
0\end{array}$ & 16.6 & $\begin{array}{c}6 \\
33.3\end{array}$ & $\begin{array}{l}0 \\
0\end{array}$ \\
\hline & Weaners & $\begin{array}{c}0 \\
7.6\end{array}$ & $\begin{array}{c}2 \\
30.7\end{array}$ & $\begin{array}{c}2 \\
23\end{array}$ & $\begin{array}{c}0 \\
30.7\end{array}$ & $\begin{array}{c}1 \\
23\end{array}$ & $\begin{array}{c}2 \\
38.4\end{array}$ & $\begin{array}{l}0 \\
0\end{array}$ \\
\hline & Suckling Piglets & $\begin{array}{l}1 \\
0\end{array}$ & $\begin{array}{c}4 \\
25\end{array}$ & $\begin{array}{c}3 \\
12.5\end{array}$ & $\begin{array}{c}4 \\
12.5\end{array}$ & $\begin{array}{c}3 \\
37.5\end{array}$ & $\begin{array}{c}5 \\
37.5\end{array}$ & $\begin{array}{l}0 \\
0\end{array}$ \\
\hline & Growing-pig & $\begin{array}{l}0 \\
0\end{array}$ & $\begin{array}{c}2 \\
100\end{array}$ & $\begin{array}{c}1 \\
50\end{array}$ & $\begin{array}{c}1 \\
100\end{array}$ & $\begin{array}{l}3 \\
0\end{array}$ & $\begin{array}{l}3 \\
0\end{array}$ & $\begin{array}{l}0 \\
0\end{array}$ \\
\hline & Boars & 0 & 2 & 1 & 2 & 0 & 0 & 0 \\
\hline
\end{tabular}

Human samples. The parasites observed in the workers of both technified farms were: In farm T1 E. coli $25 \%$, B. coli $25 \%$ and E. nana $25 \%$ was found. In farm T2 a presence of parasites such as $E$. coli $35.7 \%$ and $E$. nana by a $7.1 \%$ were evident.

In the samples gathered from humans in both semi-technified farms the following parasites were found: E. coli, B. coli, I. bütschlii, Blastocystis hominis y Entamoeba hystolitica/ dispar. In the farm ST1 a presence of E. coli $60 \%$, E. hystolitica/ dispar $40 \%$, B. coli $10 \%$ and $B$. hominis $10 \%$ was observed. In the farm ST2 $E$. coli $40 \%$ and $I$. bütschlii $20 \%$.

\section{DISCUSSION}

Comparatively, studies made in Asia (China and Turkey) report and average prevalence of B. coli $24.4 \%$, coccidian $24 \%$, Cryptosporidium spp. $8.82 \%$, Ascaris spp. $3.14 \%$, T. suis $5.2 \%$ y Giardia spp. $3.78 \%(12,17)$ while in Europe (Germany) a presence of Oesophagostomum spp., A. suum, T. suis and Eimeria spp. in $79 \%$, $7 \%, 8 \%$ y $29 \%$ each (11). In Latin America, in countries such as Cuba (18) and Perú (19) an average percentage of Coccidiosis $41.7 \%$, Oesophagostomum spp., $14.9 \%$, T. suis $14.7 \%$, A. suum $6.7 \%$ and Strongyloides spp., $5.5 \%$ were reported.

In Colombia only a few epidemiological studies about this topic have been made, thus for this reason the data about the prevalence of swine parasites is yet unknown. The results obtained
Muestras humanas. Los parásitos observados en los trabajadores de las dos granjas tecnificadas fueron: En la granja T1 se encontraron $E$. coli $25 \%$, B. coli $25 \%$ and $E$. nana $25 \%$. En la granja T2 fue evidente la presencia de parásitos como E. coli $35.7 \%$ and $E$. nana en un $7.1 \%$.

En los muestreos realizados a los humanos de las dos granjas semi-tecnificadas, fueron encontrados los siguientes parásitos: En la granja ST1 E. coli $60 \%$, E. hystolitica/dispar $40 \%$, B. coli $10 \%$ y B. hominis $10 \%$. En la granja ST2 E. coli $40 \%$ e $I$. bütschlii $20 \%$.

\section{DISCUSIÓN}

Comparativamente, los estudios realizados en Asia (China y Turquía) reportaron una prevalencia promedio de $B$. coli $24.4 \%$, coccidias $24 \%$, Cryptosporidium spp. 8.82\%, Ascaris spp. 3.14\%, T. suis $5.2 \%$ y Giardia spp. $3.78 \%(12,17)$ mientras en Europa (Alemania) la presencia de Oesophagostomum spp., A. suum, $T$. suis y Eimeria spp., fue del $79 \%, 7 \%, 8 \%$ y $29 \%$ respectivamente (11). En América Latina, países como Cuba (18) y Perú (19) reportaron un porcentaje promedio de Coccidiosis 41.7\%, Oesophagostomum spp. 14.9\%, T. suis $14.7 \%$, A. suum $6.7 \%$ y Strongyloides spp. $5.5 \%$.

En Colombia, se han realizado pocos estudios epidemiológicos sobre este tema y por esta razón aún se desconocen los datos acerca de la prevalencia de los parásitos porcinos. Los resultados obtenidos en el presente estudio coinciden con lo reportado a nivel internacional respecto a la 
in this study vs other studies related with to the presence of parasites such as B. coli, $A$. suum, T. suis, Giardia spp., Strongyloides spp., Eimeria spp. and Cryptosporidium spp., match it; whereas differs in the findings of Oesophagostomum spp., because the last one was not found in the present study.

Only few studies refer to these type of gastrointestinal parasites found by age group in swine production; nevertheless, a study made in Cuba reported $B$. coli in weaners $21 \%$, suckling piglets $20 \%$, growing-pig $30 \%$, females $16 \%$ and boars $3 \%$; $A$. suum in Weaners $12 \%$, suckling piglets $6 \%$, growing-pig, females and boars $0 \%$; $T$. suis suckling piglets $4 \%$, weaners, growingpig, females and boars 0\%; Strongyloides spp. in weaners $31 \%$, suckling piglets $0 \%$, growingpig $4 \%$, females $5 \%$ and boars $1 \%$; this study determined that the young pigs are more susceptible to parasite infections than adult pigs (20), as it was shown in the current study where young pigs showed a higher presence of some parasites. (Table 2, Table 3).

According to the data obtained and analyzed by means of the statistical $\mathrm{Chi}^{2}$ test, this study proves the existent relationship between the presence of parasites and the type of farm analyzed (semi-technified and technified farms) with a value of $p<0.001$ indicating a higher presence of parasites in the semi-technified farms; simultaneously it shows an existent relationship between the presence of parasites and the age group involved with a value of $p<0.001$. Additionally, when the test of proportion hypothesis was done it was able to determine that $B$. coli, was found in a higher proportion in technified farms than in semi-technfied farms with a value of $\mathrm{p}<0.001$. E. nana and I. bütschlii were found in a higher proportion in the semi techn farms than techn ones with a value of $p<0.01$ and $p<0.001$ respectively.

It is important to acknowledge that the higher prevalence of parasites is found in the nursing females, pregnant sows, weaners and suckling piglets in technified as in semi-technified farms as well, this higher presence in these age groups is possibly given due to the physiological conditions in which the animals are living; in the females, the stress conditions and well as the immune suppression physiological process they deal during their pregnancy period, making them more susceptible to infections by diverse parasites, thus constituting the main source of infection for the weaners (4) additionally, studies have proved that the age of the weaners is a critical factor in parasite infections, due to the high sensibility of piglets to infections by their immune immaturity in their first presencia de parásitos como B. coli, A. suum, $T$. suis, Giardia spp., Strongyloides spp., Eimeria spp., y Cryptosporidium spp., sin embargo, estos datos difieren en el hallazgo de Oesophagostomum spp., parásito no detectado en el presente estudio.

Pocos estudios hacen referencia al tipo de parásitos gastrointestinales encontrados por grupo etario en cerdos de producción; sin embargo, un estudio realizado en Cuba reportó $B$. coli en lechones destetados $21 \%$, lechones lactantes $20 \%$, cerdos de levante $30 \%$, hembras $16 \%$ y reproductores $3 \%$; A. suum en lechones destetados $12 \%$, lechones lactantes $6 \%$, cerdos de levante, hembras y reproductores $0 \%$; $T$. suis en lechones lactantes $4 \%$, lechones destetados, cerdos en levante, hembras y reproductores 0\%; Strongyloides spp. en lechones destetados $31 \%$, lechones lactantes $0 \%$, cerdos de levante $4 \%$, hembras $5 \%$ y reproductores $1 \%$; este estudio determinó que los cerdos jóvenes son más susceptibles a las infecciones parasitarias que los adultos (20), como se demostró en el presente estudio, donde los cerdos jóvenes mostraron mayor presencia de algunos parásitos. (Tabla 2, Tabla 3).

De acuerdo con la información obtenida y analizada por medio del test estadístico $\mathrm{Chi}^{2}$, este estudio demuestra la relación existente entre la presencia de parásitos y el tipo de granja analizada (granjas semitecnificadas y tecnificadas) con un valor $p<0.001$ indicando una mayor presencia de parásitos en las granjas semi-tecnificadas; simultáneamente es evidente la relación existente entre la presencia de parásitos y los grupo por edades como lo indica el valor $p<0.001$. Adicionalmente, cuando se realizó el test de hipótesis para la proporción, se pudo determinar que $B$. coli se encontraba en mayor proporción en las granjas tecnificadas que en las granjas semi-tecnificadas con un valor $\mathrm{p}<0.001$. $E$. nana e $I$. bütschlii se encontraron en mayor proporción en las granjas semi-tecnificadas que en las tecnificadas con un valor $p<0.01$ y $p<0.001$ respectivamente.

Es importante reconocer que la mayor prevalencia de parásitos se detectó en las hembras lactantes, las hembras gestantes y en los lechones lactantes y destetados, tanto en las granjas tecnificadas como en las semi-tecnificadas; esta mayor presencia en los grupos de edad se debe, posiblemente, a las condiciones fisiológicas en las que viven los animales; en las hembras, las condiciones de estrés así como el proceso fisiológico de inmunosupresión que afrontan durante su período de preñez, las hacen más susceptibles a las infecciones por diversos parásitos; constituyendose estas en la principal fuente de infección de los lechones destetados (4); adicionalmente, estudios han demostrado que la edad de los lechones destetados es un factor crítico en las infecciones parasitarias 
three days of life, whereas they achieve a high immunity against infections by their 2 week, (4). As a opposing argument to the report of the current study in, the suckling piglets with an average of 5 weeks of life, were found with a higher prevalence of parasites in both types of farms, a $50 \%$ in technified farms and a $81.3 \%$ in semi-technified farms.

It has been proven that the prevalence of parasites varies depending on the management, location, weather and deworming processes implemented in each one of the farms. (21) One of the reasons why it is believed that the presence of parasites varies from one farm to another is the weather conditions; this data is relevant for the association of certain parasite species, as the samples in both technified farms were done during the months of August and September in 2012, and according to the report by the hydrology, meteorology and environmental studies institute (IDEAM) (9), the Cundinamarca zone showed pluviosity excess (8). This could be related to the absence of some parasites that are reported in literature and were not found in the current study, such as, Oesophagostomum spp., that reports an optimum temperature for its development of $25^{\circ} \mathrm{C}$, (10) whereas for Eimeria spp. and Cryptosporidium spp. a temperature between 21 y $22^{\circ} \mathrm{C}$ is reported and optimal dry conditions for its development and latter infection (21). Thus, the above might be one of the reasons by which these parasites were not found in farms T1 and T2, due to the temperatures and pluviosity in both locations during the months of the study, and so not helping the infection of these parasites.

On the contrary, in the semi-technified farms the presence of Eimeria spp., Isospora spp. and Cryptosporidium spp. were evident and the presence Oesophagostomum spp. was not found, thus this might be related to the weather conditions during the months of April and May of 2013, during which the samples were taken and had a dry weather as reported by IDEAM. (9)

Another important condition related to the prevalence of parasites are the hygienic and sanitary conditions managed by each farm, as it can be clearly seen in the semi-technified farm ST2, were the water used for animal consumption came from a natural source without any type of treatment due to the owner of the farm who considers that the water is completely pure and so it does not need any treatment whatsoever, and thus this might be related to the high prevalence and variety of parasites found there. debido a su alta sensibilidad a las infecciones por su inmadurez inmunológicas durante sus tres primeros días de vida, mientras logran una alta inmunidad contra las infecciones a las dos semanas (4). En contraposición con lo reportado, en el presente estudio los cerdos de pre-cebo que tienen en promedio 5 semanas de vida, se encontraron con una mayor prevalencia de parásitos en los dos tipos de granjas, con un $50 \%$ en granjas tecnificadas y un $81.3 \%$ en granjas semi-tecnificadas.

Se ha demostrado que la prevalencia de los parásitos varía dependiendo del manejo, localización, clima y procesos de desparasitación implementados en las granjas (21). Una de las razones por las que se cree que la presencia de parásitos varía de una granja a otra son las condiciones climáticas; esta información es relevante para la asociación de ciertas especies parasitarias, debido a que las muestras de las dos granjas tecnificadas se obtuvieron durante los meses de agosto y septiembre de 2012, cuando la zona de Cundinamarca mostraba una pluviosidad excesiva (8) de acuerdo con el informe del Instituto de Estudios Hidrológicos, Meteorológicos y Ambientales (IDEAM) (9). Esto podría estar relacionado con la ausencia de algunos parásitos que se reportan en la literatura y no se encontraron en el estudio actual, como es el caso del Oesophagostomum spp., que se reporta en una temperatura óptima de $25^{\circ} \mathrm{C}$ para su desarrollo, (10) mientras Eimeria spp., y Cryptosporidium spp., en una temperatura entre 21 y $22^{\circ} \mathrm{C}$ y condiciones secas óptimas para su desarrollo y posterior infección (21). Así pues, lo anterior podría ser una de las razones por la que estos parásitos no se encontraron en las granjas T1 y T2, debido a que la temperatura y la pluviosidad en ambos lugares durante los meses del estudio no favorecen a la infección con estos parásitos.

Por el contrario, en las granjas semi-tecnificadas la presencia de Eimeria spp., Isospora spp. y Cryptosporidium spp. fue evidente y no se encontró Oesophagostomum spp., lo que podría estar relacionado con las condiciones climáticas durante los meses de abril y mayo de 2013, período durante el cual se tomaron las muestras y presentaba tiempo seco según lo informado por el IDEAM. (9)

Otra condición importante en cuanto a la prevalencia de parásitos son las condiciones higiénico sanitarias que se manejan en cada granja, lo que puede ser evidenciado claramente en la granja semitecnificada ST2 en donde el agua utilizada para el consumo de los animales proviene de una fuente natural sin que posiblemente tenga alguna clase de tratamiento debido a que el propietario considera que el agua es totalmente pura y no necesita tratamiento alguno, lo que puede estar relacionado con la alta prevalencia y variedad de parásitos encontrados en esta granja. 
In the present study $I$. bütschlii was found, and it is reported in literature as an intestinal non pathogen amoeba in humans, apes and swine; even though it was described as the most common intestinal amoeba in swine (22) its presence has not been reported in this host; only one study made in twelve boar intestines in Iran during 2004 showed a prevalence of $17 \%$ of $I$. bütschlii (7).

It is of relevance to acknowledge, the presence of Cryptosporidium spp. in a semi-technified farm in a very low proportion (1+) in three different age groups; the infections by this agent have a higher frequency rate in early stages as weaners and suckling piglets, whereas in adults is slightly probable; the absence of this specie in the other farms might be due to the preventive measures taken such as a pretreatment with coccidiostatics in early stages. On the contrary to the report of the literature in the current study there was evidence of the presence of Cryptosporidium spp., in suckling piglets and females stages (23).

The consistency of the fecal matter samples analyzed from humans in its majority was very soft but not watery. According to the results found in the sampling procedure done to some of the workers of both technified and semi-technified farms, a possible zoonotic process might be correlated with $B$. coli were the pigs the reservoir of the parasite and the main source of infection for the human (24). The presence of this parasite in humans is conditioned to bad health conditions, lack of basic utilities (water, sinks) and the breeding of the swine in open fields (10), this last aspect was not prevalent in the current study, due to the breeding swine in barns; nevertheless, the conditions and sanitary-hygienic habits of the humans are possibly the highest risk factors in the zoonotic processes.

In Latin America, the prevalence of the infection by $B$. coli ranges between 0.5 and $2.1 \%$ (21), showing low among other protozoan intestinal infections. The quality of the water and thus the presence of parasites, to establish with certainty what is the true source of infection and the existence of transmission between species. A wide study done in Bolivia in 2.000 samples of feces coming from Aymara native children from the Bolivian steep lands region, showed a disseminated infection by $B$. coli with a general prevalence of $1.2 \%$; besides this, swine fecal samples were analyzed, and the results showed that more than half of the swine $(n=50)$ living in this native community were infected by $B$. coli, wich clearly indicates
En el presente estudio se encontró $I$. bütschlii que es reportada como una ameba intestinal no patógena en los humanos, los monos y los cerdos; aunque fue descrita como la ameba intestinal más común de los cerdos no se ha reportado su presencia en este hospedero; solamente un estudio realizado en 12 intestinos de jabalíes examinados en Irán en el año 2004 se encontró una prevalencia del $17 \%$ para $I$. bütschlii (7).

Es importante reconocer la presencia de Cryptosporidium spp. en una granja semitecnificada en una proporción muy baja $(1+)$ en tres diferentes grupos de edad; las infecciones por este agente tienen mayor índice de frecuencia en etapas tempranas como lechones destetados y lactantes, mientras en los adultos es poco probable; la ausencia de esta especie en las otras granjas se podría deber a las medidas preventivas adoptadas, tales como el tratamiento previo con coccidiostáticos en las primeras etapas. Al contrario de lo reportado en la literatura, en el presente estudio se evidenció de la presencia de Cryptosporidium spp., en etapas de pre-cebo y en hembras (23).

La consistencia de las muestras de materia fecal analizadas procedentes de humanos en su mayoría fueron muy blandas sin llegar a ser acuosas. De acuerdo con los resultados obtenidos en los trabajadores de las granjas tecnificadas y semitecnificadas, podría correlacionarse un posible proceso zoonótico con $B$. coli donde los cerdos fueron el reservorio del parásito y la principal fuente de infección para los humanos (24). La presencia de este parásito en las personas está determinada por las malas condiciones de salubridad, carencia de servicios básicos (agua, desagüe) y crianza de cerdos a campo abierto (10); este último aspecto no fue predominante en el estudio actual debido a que la cría de los cerdos se lleva a cabo en corrales; sin embargo, las condiciones y hábitos higiénicosanitarios de los seres humanos son, posiblemente, los factores de riesgo más altos en los procesos zoonóticos.

En América Latina la prevalencia de la infección por B. coli en humanos, oscila entre el 0.5 y el $2.1 \%$ (21), siendo baja frente a otras infecciones intestinales por protozoos. Son necesarios estudios adicionales donde se evalué la calidad del agua y presencia de parásitos para saber con certeza cuál es la verdadera fuente de infección y si hay transmisión entre especies. Un amplio estudio realizado en Bolivia con 2.000 muestras de heces procedentes de niños Aymaras nativos de regiones escarpadas bolivianas, mostró una infección por $B$. coli con una prevalencia general de $1.2 \%$; adicional a esto se analizaron muestras de heces de cerdos y los resultados mostraron que más de la mitad de los cerdos $(n=50)$ que viven en esta 
a zoonotic transmission (5). The illness in swine is asymptomatic, whereas, in humans it might show clinical outcomes ranging from asymptomatic to severe ones, where the asymptomatic ones serve as reservoirs and disseminators of the illness; diarrhea, blood feces, cramps and abdomen pain is shown in the severe ones (5).

A study made in Egypt, showed the presence of de E. coli and E. histolytica/dispar in samples of swine and dogs in a $7.56 \%$ y $3.84 \%$ respectively, additionally samples of children with diarrhea were analyzed and showed a high prevalence of both species, thus suggesting a possible anthropozoonotic infection with dogs and swine in the area (25). Additionally, during the current study the presence of $E$. nana was evidenced, and from which its zoonotic potential has not been established yet, but it is said that it might be involved in zoonosis were swine and humans are in high contact with the infective form (Cysts) by water consumption, food or contaminated hands and thus helping the zoonotic pathogens transmission between species, causing disease $(7,26)$.

A study made in the Republic of Korea, related to zoonotic parasites reported that the main parasites with zoonotic potential are E. nana and $I$. bütschlii, which are protozoans with sapro-zoonotic potential, meaning humans become infected by contaminated food or water with feces of swine, dogs and cattle (7).

Another parasite found was Blastocystis hominis, which pathogen potential in humans and swine is still controversial due to the absence of symptoms, the presence of this microorganism in feces of a variety of animal species such as birds, apes, rodents, amphibians and humans suggests the rotation among them, thus considered a protozoan with zoonotic potential $(7,26)$, also it is associated with the consumption of water, fruits and vegetables contaminated with feces. This parasite is found in a high prevalence in human population, for example, in Argentina in a $43 \%$ of children in school age was found, it has been registered in Venezuela with a prevalence of $27 \%$, from which $24 \%$ of children in school age, mainly between the age of 9 and 11 years old and $23.9 \%$ of the elderly population were infected by this protozoan. (23)

Although in the analyzed humans, were not observed compatible structures with $A$. suum, $T$. suis and Cryptosporidium spp., it is of importance to stand out the zoonotic potential of these parasites. Ascaris lumbricoides and comunidad nativa estaban infectados por $B$. coli, lo cual claramente indica una transmisión zoonótica (5). La enfermedad en los cerdos es asintomática mientras en los seres humanos podría mostrar resultados clínicos que van desde asintomáticos hasta severos, donde los asintomáticos sirven como reservorios y diseminadores de la enfermedad mientras en los severos se pueden presentar diarrea, deposiciones con sangre, calambres y dolor abdominal (5).

Un estudio realizado en Egipto mostró la presencia de E. coli y E. histolytica/dispar en muestras de porcinos y caninos en el $7.56 \%$ y $3.84 \%$ respectivamente; adicionalmente se analizaron muestras de niños con diarrea que mostraron alta prevalencia a las dos especies, lo que sugiere una posible infección antropozoonótica con los perros y los cerdos de la zona (25). Adicionalmente, durante el presente estudio se evidenció la presencia de $E$. nana, cuyo potencial zoonótico no se ha establecido aún, pero se dice que podría estar involucrado en zoonosis con cerdos y los seres humanos que están en alto contacto con la forma infecciosa (quistes) por el consumo de agua, la comida o manos contaminadas, ayudando así a la transmisión de agentes patógenos zoonóticos entre las especies y causando la enfermedad $(7,26)$.

Otro estudio realizado en la República de Corea relacionado con parásitos zoonóticos reportó que los principales parásitos con potencial zoonótico son E. nana e I. bütschlii, que son protozoos con potencial sapro-zoonótico, lo que significa que los seres humanos se infectan por alimentos o agua contaminada con heces de porcinos, caninos y ganado (7).

Otro parásito encontrado fue el Blastocystis hominis, cuyo potencial patógeno en humanos y cerdos sigue siendo controvertido debido a la ausencia de síntomas; la presencia de este microorganismo en las heces de varias especies de animales como aves, monos, roedores, anfibios y los humanos sugiere la rotación entre ellas, por lo que se considera un protozoario con potencial zoonótico $(7,26)$; también se asocia con el consumo de agua, frutas y verduras contaminadas con materia fecal. Este parásito se encontró con alta prevalencia en la población humana; por ejemplo, en Argentina se halló en el $43 \%$ de los niños en edad escolar, también se ha registrado en Venezuela con una prevalencia de $27 \%$, donde el $24 \%$ de los escolares, principalmente niños entre 9 y 11 años de edad y $23.9 \%$ de los ancianos estaban parasitados por este protozoo (23).

Aunque en los seres humanos analizados no se observaron estructuras compatibles con $A$. suum, T. suis y Cryptosporidium spp., es importante destacar el potencial zoonótico de estos parásitos. Ascaris lumbricoides y Trichuris trichiura infectan a más de mil millones de personas en todo el mundo 
Trichuris trichiura, infect more than a thousand million people worldwide (27), the species $A$. suum and $T$. suis in swine have a global distribution, due to the presence of infected swine mainly in the production system (27). Swine and humans alike are infected by the ingestion of the eggs that acquire an infectious stage in the environment (26). This type of parasitosis produces high economic impact, due to the frequent delay in growth and diarrhea in swine. The differentiation between human and swine parasites species has been hard and due to this reason the frequency of infection of $A$. suum and $T$. suis in humans cannot be determined (26), but a zoonotic implication is not discarded due to it similarity and the possibility to infect humans especially in areas where swine and humans live close to each other or swine feces is used as agricultural fertilizer in vegetables for human consumption or by water pollution and bad hygiene of workers in the swine farms, thus existing a potential risk of crossed infections (27).

The cryptosporidiosis is a disease of high zoonotic importance, known worldwide as a public health problem that affects mainly people that interact with farm animals on a daily basis (5). Generally, the infections by Cryptosporidium in domestic swine are higly frequent in animals between 1 and 6 months old, reaching a prevalence between 24 and $60 \%$; the $16.5 \%$ of the adults had an infection by Cryptosporidium spp. (21), this data supports the fact that adult swine are parasited in a lower degree (21). Recent studies have showed the existence of Cryptosporidium suis, finding done by means of molecular biology which evidenced that this is genetically different from the other species of Cryptosporidium known (21).

It is relevant to evidence the presence of pathogens with zoonotic potential, thus they might prove to become relevant public health issues, besides, pitching in knowledge concerning these type of parasites, will make decision making in preventive measures that deny the rotation of parasites between animal and humans.

Infection due to contaminated water, bad human hygienic practices contributes to the transmission of parasites to swine, and thus these act as a reservoir disseminating the parasites by fecal means. When used as agricultural fertilizer it contaminates crops and water supplies acting as a source of infection for humans and animals alike in an endless cycle.
(27) y las especies $A$. suum y $T$. suis en los cerdos tienen distribución mundial debido a la presencia de cerdos infectados, principalmente en los sistemas de producción (27). Los cerdos y los seres humanos se infectan igualmente por la ingestión de huevos que son el estadío infeccioso en el medio ambiente (26). Este tipo de parasitosis produce alto impacto económico debido al retraso frecuente en el crecimiento y la diarrea en los cerdos. La diferenciación entre las especies de los parásitos en humanos y en los porcinos ha sido difícil y por esta razón la frecuencia de infección con $A$. suum y $T$. suis en humanos no se puede determinar (26), pero no se descarta una implicación zoonótica debido a su similitud y a la posibilidad de infectar a los seres humanos, especialmente en las zonas donde los cerdos y los humanos viven cerca unos de otros, o donde el estiércol porcino se utiliza como fertilizante agrícola de hortalizas destinadas al consumo humano, o por la contaminación del agua y la mala higiene de los trabajadores en las granjas porcinas, por lo que existe un riesgo potencial de infecciones cruzadas (27).

La criptosporidiosis es una enfermedad de gran importancia zoonótica, conocida en todo el mundo como un problema de salud pública que afecta principalmente a las personas que a diario interactúan con animales de granja (5). En general las infecciones por Cryptosporidium en cerdos domésticos son frecuentes en animales entre 1 y 6 meses de edad, alcanzando una prevalencia entre el 24 y el $60 \%$; el $16,5 \%$ de los adultos tuvo una infección por Cryptosporidium spp. (21), información que apoya el hecho de que los cerdos adultos están parasitados en un grado menor (21). Estudios recientes han mostrado la existencia de Cryptosporidium suis, hallazgo hecho por medio de la biología molecular, que evidencian que este parásito es genéticamente diferente de las otras especies de Cryptosporidium conocidos (21).

Es importante demostrar la presencia de patógenos con potencial zoonótico que podrían llegar a convertirse en problemas de salud pública; además, difundir el conocimiento sobre este tipo de parásitos hará tomar decisiones sobre las medidas preventivas que impidan la rotación de los parásitos entre los animales y seres humanos.

La infección por agua contaminada y las malas prácticas de higiene de los humanos contribuyen en la transmisión de parásitos a los cerdos y estos actúan como reservorio diseminando los parásitos por medio de las heces, las cuales al usarse como abono en agricultura contaminan las hortalizas y las aguas siendo fuente de infección tanto para los humanos como para otros animales siguiendo un ciclo sin fin. 


\section{Acknowledgements}

Pontificia Javeriana University. Academic research vice direction. Research proposals financed by own resources of the academic units ID PPTA 00004645, ID PRY 004437. Swine producer's Colombian association, specially the field technicians.

\section{Agradecimientos}

A la Pontificia Universidad Javeriana. Subdirección de Investigación Académica. Propuestas de investigación financiadas con recursos propios de las unidades académicas ID PPTA 00004645, ID PRY 004437. A la Asociación Colombiana de Porcicultores (ACP), especialmente a los técnicos de campo.

\section{REFERENCES}

1. DANE. Oferta agropecuaria. [in line] 2013. [Accessed 24 de Jun 2014].URL Available in: https://www.dane.gov.co/files/ investigaciones/agropecuario/ena/2013/ boletin_ena_2013.pdf

2. Frontera E, Bravo D, Blanco J, Herrador P, Calero R, Serrano F, et al. Las parasitosis porcinas y sus repercusiones económicas. Suis 2012; 87:18- 27.

3. Frontera $E$, Pérez $M$, Alcaide $M$, Reina D. Patología parasitaria porcina: en imágenes. España: Ed. Servet; 2009.

4. Cordero del Campillo M, Rojo F, Martínez A, Sánchez M, Hernández S, Navarrete I, et al. Parasitología Veterinaria. España: Ed. McGraw-Hill; 2000.

5. Weese J S, Fulford M B. Companion animal zoonoses. USA: Ed Wilwy-Blackwell; 2011.

6. Beck W, Pantechev N. Zoonosis parasitarias. España; Ed. Servet: 2009.

7. Solaymani-Mohammadi S, Petri W. Zoonotic implications of the swine-transmitted protozoal infections. Vet Parasitol 2006; 140(3-4):189-203.

8. IDEAM. Boletín informativo sobre el monitoreo de los fenómenos de variabilidad climática. Boletín número 49. [En linea]. 2012. URL Disponible en: http://www. pronosticosyalertas.gov.co/jsp/894

9. IDEAM. Boletín informativo sobre el monitoreo de los fenómenos de variabilidad climática. Boletín número 55. [En linea]. 2013. URL Disponible en: http://www. pronosticosyalertas.gov.co/jsp/894
10. Bornay F, Navarro L, Garcia F, Araez H, Perez $M$, Moral R. Detection of intestinal parasites in pig slurry: A preliminary study from five farms in Spain. Livest Sci 2006; 102(3):237-242.

11. Gerwert S, Failing K, Bauer C. Husbandry management, worm control practices and gastro-intestinal parasite infections of sows in pig-breeding farms in Munsterland, Germany. Dtsch Tierarztl Wochenschr 2004; 111(10):398-403.

12. Hayriye K, Bora Ö, Metiner K, Ilgaz A. Investigation of Intestinal Parasites in Pig Feces That Are also Human Pathogens. Türkiye Parazitol Derg 2009; 33(3):218-221.

13. Navone T, Gamboa M, Kozubsky L, Costas M, Sisliauska M, Gonzalez M. Estudio comparativo de recuperación de formas parasitarias por tres diferentes métodos de enriquecimiento coproparasitologico. Parasitol Latinoam 2005; 60(3-4):178-181.

14. Pajuelo G, Lujan D, Paredes B, Tello L. Aplicación de la técnica de sedimentación espontanea en tubo en el diagnóstico de parásitos intestinales. Rev Biomed. 2006; 17(2):96-101.

15. FAO. Techniques for parasite assays and identification in faecal samples. [On line] 2010. [Accessed 24 de Jun 2014]. URL Available in: http://www.fao.org/Wairdocs/ ILRI/x5492E/x5492e05.htm Accessed June de 2012.

16. Del Coco V, Córdoba M, Basualdo J. Cryptosporidium infection in calves from a rural area of Buenos Aires, Argentina. Vet Parasitol 2008; 158(1-2):31-35. 
17. Weng $B$, Hu, Li $Y$, Lin $Q$, Xie $H$, Gasser $B$, Zhu Q. Survey of intestinal parasites in pigs from intensive farms in guangdong province, people's republic of china. Vet Parasitol 2005; $127(3-4): 333-336$.

18. Fe Rodríguez $\mathrm{P}$, Alberto E B, Aguiar J, Rodríguez L, Hernández J A. Estudio de la prevalencia de las endoparasitosis que afectan a los cerdos en el territorio de Cuba. Rev Electrón Vet 2007; 8(4):1-15.

19. Naquira C. Las zoonosis parasitarias: problema de salud pública en el Perú. Rev Peru Med Exp Salud Publica 2010; 27(4):494-497.

20. Peguero $Y$, Guerra $Y$, Mencho J, Vázquez A. Comparación del parasitismo gastrointestinal en cerdos estatales y privados en diferentes categorías. REDVET 2006; 18(2):141-144.

21. Ryan M, Monis, Heidi L. Enemark I, Sulaiman B, Samarasinghe C, Read R. "Cryptosporidium suis n. sp. (Apicomplexa: Cryptosporidiidae) in pigs (Susscrofa)." J Parasitol 2004; 90(4):769-773.

22. Schuster, Frederick L, Ramirez-Avila, Lynn. Current World Status of Balantidium coli. J Parasitol 2008; 21(4):626-638.
23. Solarte $Y$, Peña $M$, Madera C. Transmisión de protozoarios patógenos a través del agua para consumo humano. Colomb Med 2007; 38(1):74-82.

24. Mata C, Chaves H. Balantidiasis presentación de un caso clínico. Rev Méd Universidad de Costa Rica. 2010; 5(1):58-62

25. Byomi A, Samaha H, Zidan S. Epidemiological studies on some zoonotic enteric protozoa in different areas of Nile delta. JASMR 2010; 5(2):199-207.

26. Thompson R, Smith A. Zoonotic enteric protozoa. Vet Parasitol 2011; 182(1):70-78.

27. Nejsum $P$, Betson $M$, Bendall RP, Thamsborg SM, Stothard JR. Assessing the zoonotic potential of Ascaris suum and Trichuris suis: looking to the future from an analysis of the past. Journ helm 2012; 86(2): 148-155. 